\title{
Modified atmosphere and humidity packages for conservation of paper antiques
}

Received: January 4, 2006 / Accepted: July 19, 2006 / Published online: October 4, 2006

\begin{abstract}
Modified atmosphere and humidity (MAH) agents were developed to manipulate the gas composition and humidity for controlling the foxing of paper materials during storage. Sodium ascorbate, sodium carbonate decahydrate, ferrous sulfate heptahydrate, and silica gel were selected as the basic ingredients to formulate the MAH agents that could effectively remove oxygen, release carbon dioxide, and control the relative humidity (RH). With all the MAH agents developed in our study, RH was reduced and maintained without decreasing the $\mathrm{MAH}$ efficiency. To evaluate the inhibition of microorganisms on antique paper by MAH agents, the properties of Wikstroemia papers were measured after accelerated aging and inoculation with Aspergillus flavus and Penicillium citrinum. Under high $(90 \%)$ or low $(50 \%)$ RH conditions, as long as MAH agents were used, even after 80 days, the color difference value of Wikstroemia paper was kept below 1.5 and foxing was not found. Paper packaged without MAH agents and under RH as high as $90 \%$ showed a substantial color difference in 60 days. Snowflake-like foxing was also found by ultraviolet light inspection. Wikstroemia paper inoculated with $P$. citrinum without an MAH agent showed a significant color difference in 80 days.
\end{abstract}

Key words Modified atmosphere and humidity (MAH) package $\cdot$ Foxing $\cdot$ Color difference $\cdot$ Conservation $\cdot$ Paper antiques

L.-D. Lin

Department of Forest Products Science, National Chiayi University, Chiayi 60004, Taiwan

C.-M. Hsieh · M.-J. Tsai $(\bowtie)$

School of Forestry and Resource Conservation, College of

Bio-Resource and Agriculture, National Taiwan University, No.1,

Sec.4, Roosevelt Road, Taipei 10608, Taiwan

Tel. +886-2-33664641; Fax +886-2-23686335

e-mail: tmj@ntu.edu.tw

B.-H. Chiang

Institute of Food Science and Technology, National Taiwan

University, Taipei 10608, Taiwan

\section{Introduction}

The deterioration of paper constituting books and archival materials because of the degradation of its cellulose component has been recognized since the turn of the twentieth century. ${ }^{1-3}$ The principal changes in the structure of cellulose involve biodegradation, photodegradation, acid hydrolysis, and oxidation. ${ }^{4-6}$ In general, the degradation of paper antiques is caused by a combination of the effects of air (especially $\mathrm{O}_{2}$ ), relative humidity (RH), light, insects, and microorganisms. ${ }^{7-11}$ To determine the effectiveness of conserving paper antiques, chemical insecticides and fungicides have been used in some museums to obtain an instant improvement in the storage environment and to prevent molding. However, the chemicals in insecticides and fungicides are likely to damage paper antiques, and are not environmentally friendly. ${ }^{12}$

In recent years, there has been widespread investigation into the use of low- $\mathrm{O}_{2}$ methods to control insects and microorganisms, ${ }^{13,14}$ microwave methods ${ }^{15}$ for eradicating microorganisms, and methods that alter the air composition in a closed chamber. For methods involving a low $\mathrm{O}_{2}$ concentration, the use of vacuum, $\mathrm{O}_{2}$ absorbers, and $\mathrm{N}_{2}$ and $\mathrm{CO}_{2}$ gas infusion can be applied separately or combined for the packaging of paper antiques. ${ }^{16}$

For microwave methods, the longer the treatment time for paper antiques, the greater was the effect of microorganism eradication; however, the properties of the paper were degraded simultaneously. ${ }^{15}$ Moreover, there is risk of burning paper antiques during microwave treatment. The use of a replacement gas (e.g. $\mathrm{N}_{2}$ ) or vacuum packaging can reduce the problem of the oxidation of paper antiques. However, $2 \%-3 \% \mathrm{O}_{2}$ still remains after mechanical infusion of $\mathrm{N}_{2}$ in the package, which will still cause oxidation, foxing, molding, and color changes in paper antiques, ${ }^{17}$ thus degrading the quality of paper antiques and shortening their storage life. Brittle paper antiques are likely to be damaged by vacuum packaging methods. Once the new technology involving modified atmosphere (MA) agents is fully developed, ${ }^{18}$ the problem of the remaining $\mathrm{O}_{2}$ is able to be solved. 
Antiques of different materials require different storage humidities. However, if a humidity controller is added to decrease the RH, the efficiency of MA agents may also be affected. $^{18}$

The purpose of this study was to develop modified atmosphere and humidity (MAH) agents with better gas composition manipulation and humidity control for controlling foxing of paper materials during their storage. Wikstroemia paper was selected for our study and was inoculated with Aspergillus flavus or Penicillium citrinum after accelerated aging. The effect of microorganism inhibition using MAH agents in the packaging storage of paper antiques was investigated.

\section{Materials and methods}

Antique paper

In a practical sense, any kind of suitably fibrous material can be made into paper. Since the eleventh century, Chinese artists have been fond of using hand-made paper made from phloem fibers, especially in Hsuan county, and thus the traditional name of Hsuan paper emerged. One of the most famous Hsuan papers is made from Wikstroemia canescens, which typically possesses slender fibers about $4.0 \mathrm{~mm}$ long and $10 \mu \mathrm{m}$ wide with a low average lignin content of about $10 \%$; these properties contribute to its extraordinary characteristics in papermaking. Wikstroemia paper was selected as the antique paper for this study because of its popularity for use in traditional Chinese paintings and calligraphy.

\section{Microorganisms}

Aspergillus flavus Link (CCRC no. 32113) and Penicillium citrinum Thom (CCRC no. 32382) are very common fungi ${ }^{19-21}$ and they were selected for biodeterioration experiments on Wikstroemia paper.

\section{Chemicals}

For the preparation of MAH agents, the following chemicals were used: sodium ascorbate (SA) $\left(\mathrm{NaC}_{6} \mathrm{H}_{7} \mathrm{O}_{6}\right.$, Sigma); ferrous sulfate heptahydrate (FS) $\left(\mathrm{FeSO}_{4} 7 \mathrm{H}_{2} \mathrm{O}\right.$, Riedelde Haen); sodium carbonate decahydrate (SC) $\left(\mathrm{Na}_{2} \mathrm{CO}_{3}\right.$ $10 \mathrm{H}_{2} \mathrm{O}$, Riedel-de Haen); and silica gel (Riedel-de Haen).

\section{Preparation of MAH agents}

MA agents with two different modes of action were prepared. One agent to control low $\mathrm{O}_{2}$ and high $\mathrm{CO}_{2}$ concentrations was adopted from the food science field, ${ }^{18}$ with a composition of $1.3 \mathrm{~g}$ of SA, $2.6 \mathrm{~g}$ of SC, and $2.2 \mathrm{~g}$ of FS in a 285-ml flask. Another type of agent, used to control low $\mathrm{O}_{2}$ concentrations, was tested in a preliminary study and was finally prepared with a composition of $0.8 \mathrm{~g}$ of SA and $3.0 \mathrm{~g}$ of SC. The gas composition in each test was analyzed for both systems by gas chromatography (GC) (GC-320, Gasukuro Kogyo) after 5 days.

In addition to the two major types of MA agent, silica gel with a particle diameter of $2-3 \mathrm{~mm}$ instead of $1-3 \mathrm{~mm}^{18}$ was added as a humidity controller in a gas-proved low-density polyethylene $(\mathrm{LDPE})$ package measuring $85 \times 60 \mathrm{~mm}$. The concentrations of $\mathrm{O}_{2}$ and $\mathrm{CO}_{2}$ for each different type of packaging were monitored using Gaspace 2-V3.3 software (Systech Instruments, Thame, Oxfordshire, UK) during 2, 4 , and 7 days of storage, with air calibration.

SC was first ground and prepared in powder form (60$100 \mathrm{mesh})$. FS was also in powder form (140-270 mesh) at $5^{\circ} \mathrm{C}$. Silica gel was sieved to $2-3 \mathrm{~mm}$ and was kept dried. SC and FS were mixed evenly in a fully $\mathrm{N}_{2}$-infused LDPE package $(85 \times 60 \mathrm{~mm})$ at $25^{\circ} \mathrm{C}$ and placed into a 285 - $\mathrm{ml}$ flask with $1-4 \mathrm{~g}$ of silica gel. The gas composition and $\mathrm{RH}$ were analyzed every $12 \mathrm{~h}$ using GC and a hygrometer (Hygro Estern $\mathrm{M}-4)$, respectively.

\section{Effects of MAH packages on foxing}

To determine the microorganism inhibition efficiency of MAH agents, Wikstroemia paper was inoculated with $A$. flavus or $P$. citrinum after accelerated aging under conditions of $85^{\circ} \mathrm{C}$ and $65 \% \mathrm{RH}$ for $264 \mathrm{~h}^{22}$

Aspergillus flavus and $P$. citrinum were cultured on potato dextrose agar (PDA) at $25^{\circ} \mathrm{C}$. When the spores had spread over $90 \%$ of the plate, they were washed off and collected using sterilized water, and were used to prepare a suspension of $10^{6}-10^{7}$ spores $/ \mathrm{ml}$, which was checked using a hemocytometer. Then $1 \mathrm{ml}$ of suspension was inoculated onto the center of each aged paper sample for test. Specimens were placed in darkness at $90 \%$ or $50 \% \mathrm{RH}$ for 1 day for preconditioning. Then the inoculated Wikstroemia paper samples were stored in darkness with MA or MAH agents at $25^{\circ} \mathrm{C}$. Samples were collected at 20-day intervals for measurement of color difference $\left(\Delta E^{*}\right)$; foxing appearance was checked under ultraviolet (UV) light.

\section{Color difference, $\Delta E^{*}$}

Color measurements were conducted using a color difference meter (Dr Lange, LMG082). Tristumulus values $X, Y$, and $Z$ for all specimens were obtained directly from the colorimeter. The recommended Commission International de l'Eclairage (CIE) color parameters $L^{*}$ (lightness), $a^{*}$ (along the $X$-axis, red-green), and $b^{*}$ (along the $Y$ axis, yellow-blue) were then computed to calculate the color difference $\left(\Delta E^{*}\right)$ based on the following formulae: $\Delta L^{*}=L_{\mathrm{i}}^{*}-L_{0}^{*} ; \Delta a^{*}=a_{\mathrm{i}}^{*}-a_{0}^{*} ; \Delta b^{*}=b_{\mathrm{i}}^{*}-b_{0}^{*} ; \Delta E^{*}=$ $\left[\left(\Delta L^{*}\right)^{2}+\left(\Delta a^{*}\right)^{2}+\left(\Delta b^{*}\right)^{2}\right]^{1 / 2}$; where the subscripts 0 and $\mathrm{i}$ indicate the values obtained from inoculated paper packaged without MAH (control group) and with MAH agents, respectively.

The yellowness index (YI) and brightness retention rate $(\mathrm{BR} \%)$ of the specimens were calculated with the following formulae: $\mathrm{YI}=100(1.28 X-1.06 Z) / Y$; $\mathrm{BR} \%=Y_{\mathrm{i}} / Y_{0}$; where $Y_{\mathrm{i}}$ and $Y_{0}$ are the yellowness index of inoculated paper 
packaged with MAH agents and without MAH (control group), respectively.

\section{Foxing inspection of Wikstroemia paper}

Aspergillus flavus and P. citrinum are known as paperfoxing microorganisms, which cause a change in color and damage to paper materials. Foxing on Wikstroemia paper was investigated both with the naked eye and under UV light of $365 \mathrm{~nm}$ (Spectroline ENF-2400). A fluorescent response indicated the existence of foxing caused by microorganisms.

\section{Results and discussion}

\section{Efficiency of MA agents}

MA agents used to control $\mathrm{O}_{2}$ to low concentration and $\mathrm{CO}_{2}$ to high concentration were developed to give a final $\mathrm{CO}_{2}$ release ratio of $21.56 \%(\mathrm{w} / \mathrm{w})$ and $\mathrm{O}_{2}$ release ratio of $0.72 \%$, with RH of $88.1 \% \pm 1.9 \%$. The MA agent for control of low $\mathrm{O}_{2}$ concentrations was developed to decrease the $\mathrm{O}_{2}$ level to $1.39 \%$, with $\mathrm{RH}$ of $84.3 \% \pm 2.0 \%$ over a period of 4 days.

\section{Effect of silica gel on efficiency of the MA agent}

MAH agents combined with $0.8 \mathrm{~g}$ SA and $3.0 \mathrm{~g} \mathrm{SC}$ as an $\mathrm{O}_{2}$ absorber and silica gel of $2-3 \mathrm{~mm}$ diameter $(1,2,3$, or $4 \mathrm{~g})$ were used for humidity control. As shown in Fig. 1, when silica gel was added to a low- $\mathrm{O}_{2}$ MA, the $\mathrm{O}_{2}$ concentration decreased from $21 \%$ to less than $3.5 \%$ in the first $48 \mathrm{~h}$; after $84 \mathrm{~h}$, the $\mathrm{O}_{2}$ concentration was controlled at $1.0 \% \pm 0.5 \%$.

As silica gel $(1-4 \mathrm{~g})$ was added, the $\mathrm{O}_{2}$ consumption rate was affected only in the early period. It was reasonable to assume that silica gel competed in the early stage with SA to react with the $10 \mathrm{H}_{2} \mathrm{O}$ in $\mathrm{SC}$, which delayed the dissociation of SA into $\mathrm{Na}^{+}$and ascorbate ions and thus delayed $\mathrm{O}_{2}$

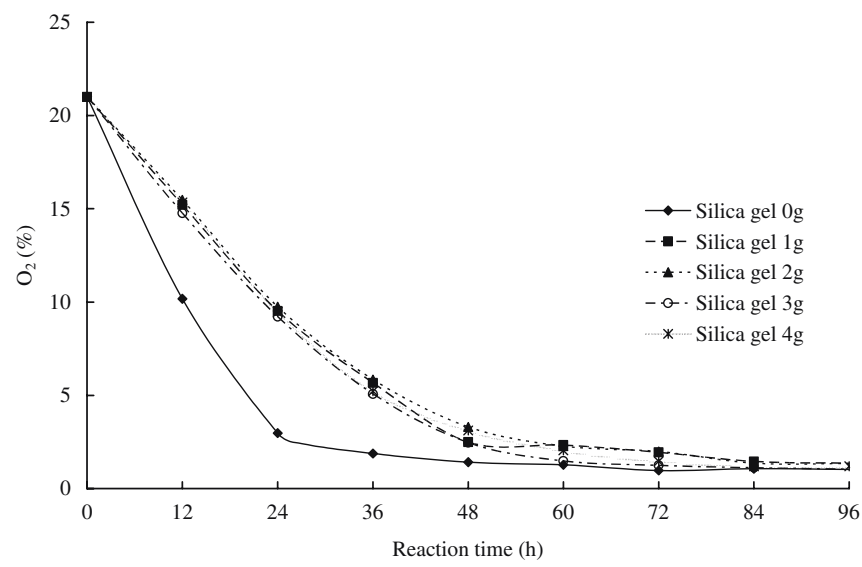

Fig. 1. Effect of silica gel on the $\mathrm{O}_{2}$ consumption rate of the modified atmosphere (MA) agent in a $285-\mathrm{ml}$ flask at $25^{\circ} \mathrm{C}$ [sodium ascorbate (SA), $0.8 \mathrm{~g}$; sodium carbonate decahydrate (SC), $3.0 \mathrm{~g}$ ] consumption. After the $\mathrm{H}_{2} \mathrm{O}$ of $\mathrm{SC}$ was released and an alkaline environment developed after $48 \mathrm{~h}$, SA oxidation was then accelerated to reach a stable $\mathrm{O}_{2}$ concentration in $96 \mathrm{~h}$. For reaction time longer than $96 \mathrm{~h}$, the use of silica gel considerably enhanced the decrease in $\mathrm{O}_{2}$ level $(<1.0 \% \pm$ $0.5 \%)$.

The agent composed of $1.3 \mathrm{~g} \mathrm{SA}, 2.6 \mathrm{~g} \mathrm{SC}, 2.2 \mathrm{~g} \mathrm{FS}$, and $0-4 \mathrm{~g}$ silica gel $(2-3 \mathrm{~mm})$ was used to reduce $\mathrm{O}_{2}$ and release $\mathrm{CO}_{2}$ with $\mathrm{RH}$ control. The $\mathrm{CO}_{2}$ release rate is plotted in Fig. 2 , showing hindrance of $\mathrm{CO}_{2}$ release over $24 \mathrm{~h}$ with increasing amounts of silica gel. However, the amount of silica gel added is irrelevant to the $\mathrm{CO}_{2}$ release rate of the MA agent developed after $48 \mathrm{~h}$. After adding $1-4 \mathrm{~g}$ of silica gel (2$3 \mathrm{~mm}$ ), the MA agent consumed $\mathrm{O}_{2}$ and decreased its concentration from $21 \%$ to less than $1.0 \% \pm 0.5 \%$ after $48 \mathrm{~h}$ (Fig. 3). The seven binding water molecules of FS and ten binding water molecules of SC, which provided the $\mathrm{H}_{2} \mathrm{O}$ sources to react with SA functioning as a low- $\mathrm{O}_{2} /$ high- $\mathrm{CO}_{2}$ agent, were used in this study. FS dissociates into $\mathrm{Fe}^{2+}$ and $\mathrm{SO}_{4}^{2-}$ in water and releases $\mathrm{H}^{+}$in the oxidation process, forming $\mathrm{CO}_{2}$ gas after reacting with $\mathrm{SC}$.

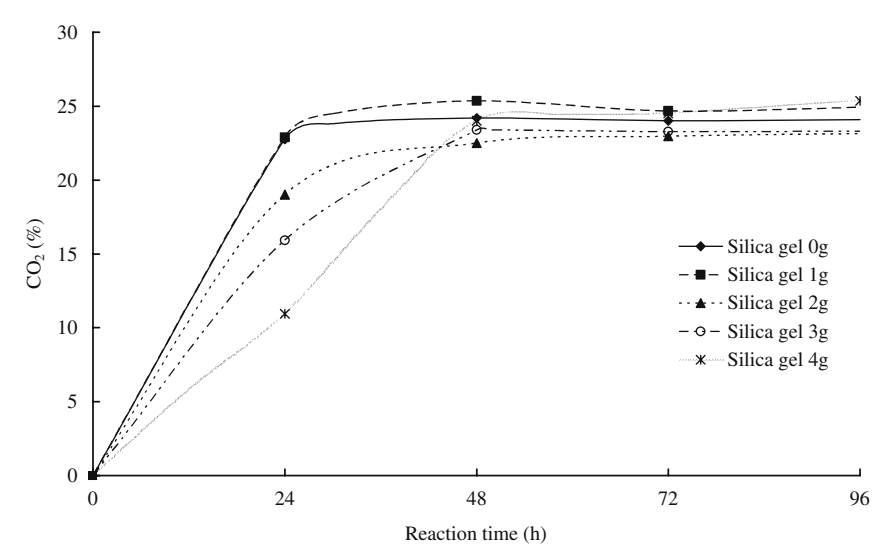

Fig. 2. Effect of silica gel on the $\mathrm{CO}_{2}$ release rate of the MA agent in a $285-\mathrm{ml}$ flask at $25^{\circ} \mathrm{C}$ [SA, $1.3 \mathrm{~g}$; SC, $2.6 \mathrm{~g}$; ferrous sulfate heptahydrate (FS), $2.2 \mathrm{~g}]$

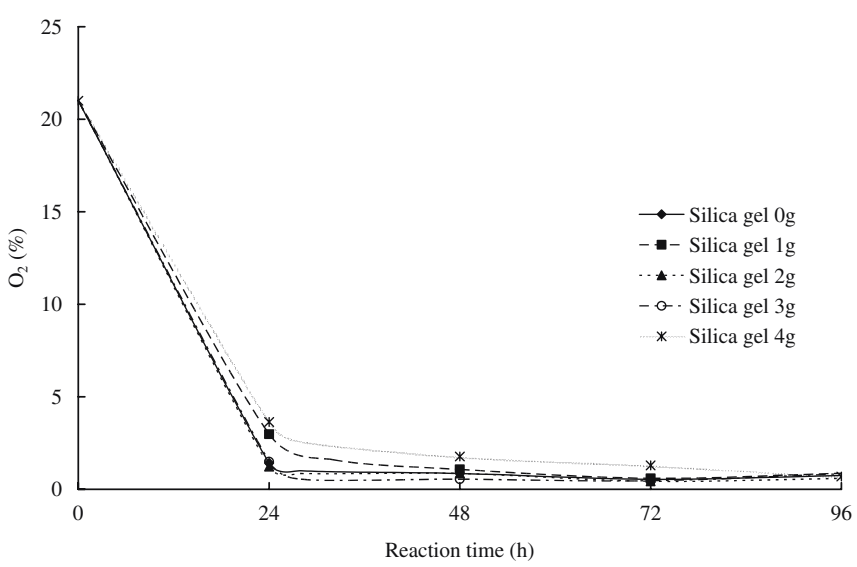

Fig. 3. Effect of silica gel on the $\mathrm{O}_{2}$ consumption rate of the MA agent in a $285-\mathrm{ml}$ flask at $25^{\circ} \mathrm{C}(\mathrm{SA}, 1.3 \mathrm{~g}$; SC, $2.6 \mathrm{~g} ; \mathrm{FS}, 2.2 \mathrm{~g})$ 
The effects of silica gel $(0-4 \mathrm{~g})$ on RH control in a $285-\mathrm{ml}$ flask after 5 days with MA agents are shown in Fig. 4. The RH decreased with increasing amounts of silica gel in packages with either a low- $\mathrm{O}_{2}$ or low- $\mathrm{O}_{2} /$ high- $\mathrm{CO}_{2}$ agent. Figures 1-3 show that the $\mathrm{O}_{2}$ consumption rate decreased in the early stage when silica gel was used; the agents producing low $\mathrm{O}_{2}$ and high $\mathrm{CO}_{2}$ were also affected in the $\mathrm{CO}_{2}$ release in the initial stage. However, as shown in Fig. 4, when silica gel was added, the aim of decreasing the $\mathrm{RH}$ was achieved in 5 days. After $48 \mathrm{~h}$, the formation of $\mathrm{CO}_{2}$ was still higher than $20 \%$ (Fig. 2), with the $\mathrm{O}_{2}$ level below $1.0 \% \pm 0.5 \%$ (Fig. 3).

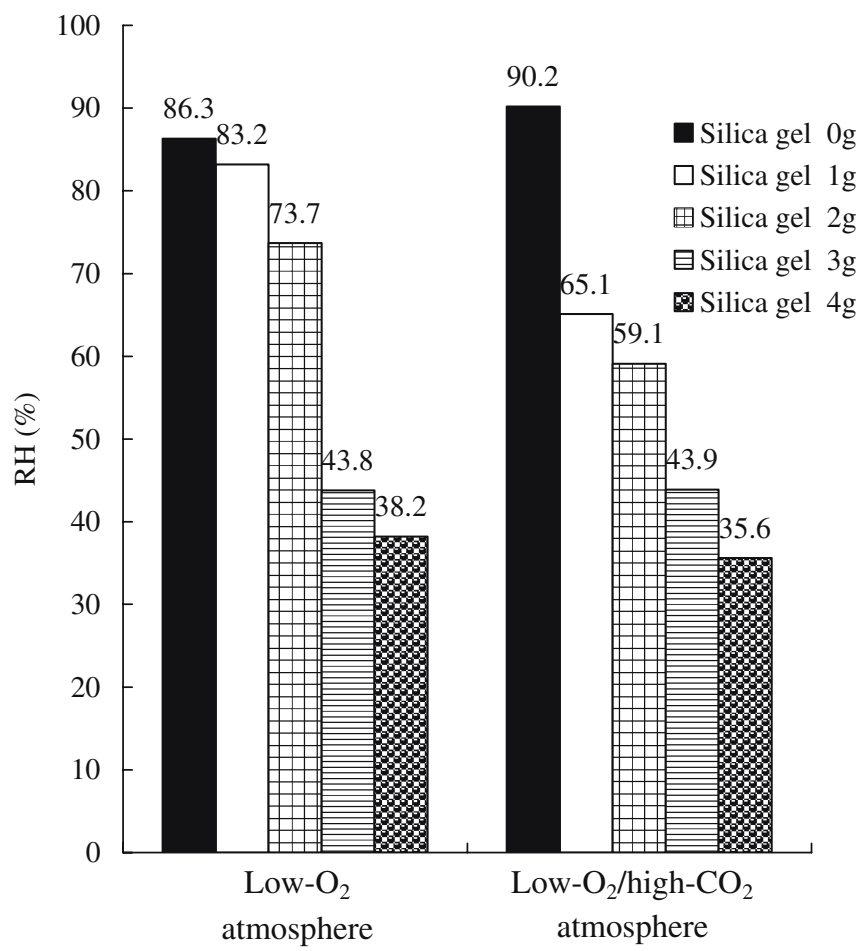

Gas composition

Fig. 4. Effect of silica gel on relative humidity $(R H)$ with MA agent in a 285-ml flask after 5 days
From the point of view of $\mathrm{O}_{2}$ consumption, Figs. 1 and 3 show that the rate for the low- $\mathrm{O}_{2}$ /high- $\mathrm{CO}_{2}$ MA agent was higher than that for the low- $\mathrm{O}_{2} \mathrm{MA}$ agent. Combined with silica gel, the low- $\mathrm{O}_{2} /$ high- $\mathrm{CO}_{2} \mathrm{MA}$ agent showed a better effect than that of the low- $\mathrm{O}_{2}$ MA agent when the amount of silica gel used was $1-2 \mathrm{~g}$. When this was increased to $3 \mathrm{~g}$, both MA agents gave promising RH control, at $44 \% \mathrm{RH}$, which is a very good $\mathrm{RH}$ environment for paper antiques. ${ }^{23}$

Effects of MAH agents on prevention of foxing

\section{Changes in surface color}

The $L^{*}$ value represents the lightness of test material, and the $\Delta L^{*}$ value is the difference in $L^{*}$ before and after accelerated aging. When the $\Delta L^{*}$ value is positive $(+)$, this indicates higher lightness after accelerated aging; when the $\Delta L^{*}$ value is negative (-), this indicates lower lightness after accelerated aging. As shown in Table 1, the $\Delta L^{*}$ value of Wikstroemia paper inoculated with Penicillium citrinum decreased under storage at $25^{\circ} \mathrm{C}$ and $90 \% \mathrm{RH}$ under nor$\mathrm{mal}$ atmospheric conditions after 60 days. After 80 days, the $\Delta L^{*}$ value was even lower. On the other hand, paper inoculated with Aspergillus flavus and stored at $25^{\circ} \mathrm{C}$ and $50 \%$ RH showed no significant difference in the $\Delta L^{*}$ value between day 60 and day 80 .

Under normal atmospheric conditions, paper inoculated with either fungus stored at $90 \% \mathrm{RH}$ gave significantly darker results, i.e. $\Delta L^{*}$ values below -1.0 . With MA agents, the decrease in lightness was greater for inoculated Wikstroemia paper in a low- $\mathrm{O}_{2}$ atmosphere than for that in a low $-\mathrm{O}_{2} /$ high- $\mathrm{CO}_{2}$ atmosphere at $90 \%$ or $50 \% \mathrm{RH}$. The $\Delta L^{*}$ values of inoculated paper under reagent-controlled conditions exhibited only very slight color differences.

The $a^{*}$ parameter represents color difference on the redgreen axis. The $\Delta a^{*}$ value is the difference in $a^{*}$ before and after aging. A positive $(+) \Delta a^{*}$ value means that the color of the paper has shifted toward red and a negative (-) $\Delta a^{*}$ value means the color has shifted to green. Comparison of the

Table 1. Effect of different gas compositions and accelerated aging conditions on $\Delta L^{*}, \Delta a^{*}$, and $\Delta b^{*}$ for Wikstroemia paper inoculated with Penicillium citrinum or Aspergillus flavus

\begin{tabular}{|c|c|c|c|c|c|c|c|}
\hline \multirow{2}{*}{$\begin{array}{l}\text { Gas } \\
\text { composition }\end{array}$} & \multirow{2}{*}{$\begin{array}{l}\text { Accelerated } \\
\text { aging conditions }\end{array}$} & \multicolumn{2}{|l|}{$\Delta L^{*}$} & \multicolumn{2}{|l|}{$\Delta a^{*}$} & \multicolumn{2}{|l|}{$\Delta b^{*}$} \\
\hline & & P. citrinum & A. flavus & P. citrinum & A. flavus & P. citrinum & A. flavus \\
\hline $\begin{array}{l}\text { Low- } \mathrm{O}_{2} \\
\quad \text { atmosphere }\end{array}$ & $\begin{array}{l}\text { I } \\
\text { II } \\
\text { III } \\
\text { IV }\end{array}$ & $\begin{array}{l}-0.7 \\
-0.6 \\
-0.6 \\
-0.7\end{array}$ & $\begin{array}{r}0.3 \\
0.0 \\
0.1 \\
-0.1\end{array}$ & $\begin{array}{l}-0.6 \\
-0.6 \\
-0.8 \\
-1.0\end{array}$ & $\begin{array}{r}-0.5 \\
0.2 \\
-0.4 \\
-0.1\end{array}$ & $\begin{array}{l}0.5 \\
0.2 \\
0.4 \\
0.5\end{array}$ & $\begin{array}{r}0.0 \\
-0.2 \\
0.0 \\
-0.6\end{array}$ \\
\hline $\begin{array}{l}\text { Low- } \mathrm{O}_{2} / \\
\text { high- } \mathrm{CO}_{2} \\
\text { atmosphere }\end{array}$ & $\begin{array}{l}\text { I } \\
\text { II } \\
\text { III } \\
\text { IV }\end{array}$ & $\begin{array}{r}-0.2 \\
-0.2 \\
0.2 \\
0.0\end{array}$ & $\begin{array}{l}0.2 \\
0.9 \\
0.5 \\
0.0\end{array}$ & $\begin{array}{l}-0.8 \\
-1.1 \\
-0.9 \\
-1.1\end{array}$ & $\begin{array}{l}-0.7 \\
-0.4 \\
-0.9 \\
-0.7\end{array}$ & $\begin{array}{l}0.6 \\
0.5 \\
0.9 \\
0.8\end{array}$ & $\begin{array}{l}0.4 \\
0.2 \\
0.2 \\
0.1\end{array}$ \\
\hline $\begin{array}{l}\text { Normal } \\
\text { atmosphere }\end{array}$ & $\begin{array}{l}\text { I } \\
\text { II } \\
\text { III } \\
\text { IV }\end{array}$ & $\begin{array}{l}-1.6 \\
-3.5 \\
-1.2 \\
-0.7\end{array}$ & $\begin{array}{r}-1.3 \\
-1.6 \\
-0.5 \\
0.2\end{array}$ & $\begin{array}{r}-1.3 \\
0.6 \\
-0.6 \\
-0.2\end{array}$ & $\begin{array}{r}0.2 \\
0.6 \\
0.2 \\
-0.6\end{array}$ & $\begin{array}{l}0.4 \\
0.8 \\
0.1 \\
0.2\end{array}$ & $\begin{array}{r}0.3 \\
1.4 \\
-0.4 \\
-0.4\end{array}$ \\
\hline
\end{tabular}

I, 90\% relative humidity (RH) 60 days; II, 90\% RH 80 days; III, 50\% RH 60 days; IV, 50\% RH 80 days 
Table 2. Effect of different gas compositions and accelerated aging conditions on yellowness index (YI), brightness retention (BR), and $\Delta E^{*}$ for Wikstroemia paper inoculated with Penicillium citrinum and Aspergillus flavus

\begin{tabular}{|c|c|c|c|c|c|c|c|}
\hline \multirow{2}{*}{$\begin{array}{l}\text { Gas } \\
\text { composition }\end{array}$} & \multirow{2}{*}{$\begin{array}{l}\text { Accelerated } \\
\text { aging conditions }\end{array}$} & \multicolumn{2}{|l|}{ YI } & \multicolumn{2}{|l|}{ BR (\%) } & \multicolumn{2}{|l|}{$\Delta E^{*}$} \\
\hline & & P. citrinum & A. flavus & P. citrinum & A. flavus & P. citrinum & A. flavus \\
\hline Control $^{\mathrm{a}}$ & - & 30.4 & 32.4 & 100.0 & 100.0 & - & - \\
\hline $\begin{array}{l}\text { Low- } \mathrm{O}_{2} \\
\quad \text { atmosphere }\end{array}$ & $\begin{array}{l}\text { I } \\
\text { II } \\
\text { III } \\
\text { IV }\end{array}$ & $\begin{array}{l}31.9 \\
31.3 \\
31.5 \\
31.4\end{array}$ & $\begin{array}{l}32.0 \\
32.2 \\
32.0 \\
31.2\end{array}$ & $\begin{array}{l}98.0 \\
98.2 \\
98.2 \\
97.9\end{array}$ & $\begin{array}{r}100.7 \\
100.1 \\
100.3 \\
99.8\end{array}$ & $\begin{array}{l}1.5 \\
1.1 \\
1.2 \\
1.5\end{array}$ & $\begin{array}{l}0.8 \\
0.7 \\
0.7 \\
1.0\end{array}$ \\
\hline $\begin{array}{l}\text { Low- } \mathrm{O}_{2} / \\
\text { high- } \mathrm{CO}_{2} \\
\text { atmosphere }\end{array}$ & $\begin{array}{l}\text { I } \\
\text { II } \\
\text { III } \\
\text { IV }\end{array}$ & $\begin{array}{l}31.7 \\
31.4 \\
32.0 \\
31.7\end{array}$ & $\begin{array}{l}32.5 \\
32.2 \\
31.8 \\
31.9\end{array}$ & $\begin{array}{r}99.3 \\
99.4 \\
100.6 \\
100.0\end{array}$ & $\begin{array}{l}100.5 \\
102.8 \\
101.6 \\
100.0\end{array}$ & $\begin{array}{l}1.2 \\
1.3 \\
1.5 \\
1.5\end{array}$ & $\begin{array}{l}0.9 \\
1.1 \\
1.1 \\
1.1\end{array}$ \\
\hline $\begin{array}{l}\text { Normal } \\
\quad \text { atmosphere }\end{array}$ & $\begin{array}{l}\text { I } \\
\text { II } \\
\text { III } \\
\text { IV }\end{array}$ & $\begin{array}{l}31.3 \\
33.9 \\
31.3 \\
31.6\end{array}$ & $\begin{array}{l}33.4 \\
35.7 \\
32.0 \\
31.2\end{array}$ & $\begin{array}{l}95.5 \\
90.0 \\
96.7 \\
98.0\end{array}$ & $\begin{array}{r}96.2 \\
95.5 \\
98.6 \\
100.7\end{array}$ & $\begin{array}{l}2.2 \\
3.9 \\
0.9 \\
1.5\end{array}$ & $\begin{array}{l}1.6 \\
2.7 \\
0.8 \\
1.8\end{array}$ \\
\hline
\end{tabular}

${ }^{a}$ The control was measured directly after accelerated aging, with 0 days of storage

effects of gas compositions on $\Delta a^{*}$ value for Wikstroemia paper inoculated with either P. citrinum or A. flavus and stored under reagent-controlled conditions showed a slightly greater tendency to shift to green (Table 1).

The $b^{*}$ parameter represents color difference on the yellow-blue axis. $\Delta b^{*}$ is the difference in $b^{*}$ before and after aging. A positive (+) $\Delta b^{*}$ value means that the color of the paper has shifted toward yellow and a negative $(-) \Delta b^{*}$ value means the color has shifted to blue. As shown in Table 1, paper inoculated with $P$. citrinum exhibited a greater tendency to shift toward yellow than paper inoculated with $A$. flavus. Paper stored under normal atmospheric conditions without reagents exhibited a significant difference between high RH conditions and low RH conditions inoculated with either $P$. citrinum or $A$. flavus. Inoculated paper preserved with reagent showed variation from the above tendency.

YI represents the yellowness index. The higher the YI value, the yellower the paper. Table 2 demonstrates that inoculated paper stored at $90 \% \mathrm{RH}$ showed substantially increased YI values after 80 days, with the YI value of paper inoculated with $A$. flavus reaching 35.7 and that with $P$. citrinum reaching 33.9. YI values for inoculated paper stored in a reagent-controlled environment or at low $\mathrm{RH}$ without agent (i.e., $50 \%$ RH only) showed only slight differences between 60 and 80 days.

$\mathrm{BR} \%$ represents the brightness retention. For Wikstroemia paper inoculated with $P$. citrinum stored at $90 \% \mathrm{RH}$ without MA or MAH agents, BR $\%$ decreased to $95.5 \%$ after 60 days and to $90.0 \%$ after 80 days. For paper inoculated with $A$. flavus and stored under the same conditions, BR \% decreased to $96.2 \%$ and to $95.5 \%$, respectively. Aspergillus flavus showed a less harmful effect than $P$. citrinum in terms of $\mathrm{BR} \%$ with or without reagent control in this study. Paper preserved with an MA package and stored at $90 \%$ or $50 \% \mathrm{RH}$ for 60 or 80 days showed only a slight decrease or no decrease in $\mathrm{BR} \%$.

A $\Delta E^{*}$ value of $1.5-3.0$ is defined as noticeable, and 3.0 6.0 is defined as an appreciable difference. ${ }^{24}$ Paper inocu- lated with $P$. citrinum and stored at $90 \% \mathrm{RH}$ without an MA package showed a noticeable $\Delta E^{*}$ value (2.2) after 60 days and an appreciable $\Delta E^{*}$ value (3.9) after 80 days. Paper inoculated with $A$. flavus and stored under the same conditions showed a noticeable $\Delta E^{*}$ value (1.6) after 60 days and a noticeable $\Delta E^{*}$ value (2.7) after 80 days.

For paper preserved with an MA package and stored either in a low- $\mathrm{O}_{2}$ or low- $\mathrm{O}_{2} /$ high- $\mathrm{CO}_{2}$ atmosphere at either $90 \%$ or $50 \% \mathrm{RH}$ for 60 or 80 days, $\Delta E^{*}$ values were all 1.5 or less. According to statistical analysis, significant differences $(P<0.05)$ did not exist for the color difference between paper specimens preserved with an MA package.

\section{Appearance of foxing}

$\mathrm{Arai}^{25}$ indicated that there is a close relationship between foxing formation and fungi. Aspergillus flavus and $P$. citrinum have been reported to cause foxing and changes in color on papers. ${ }^{24}$ Cain and Miller ${ }^{26}$ have observed the nature of foxing by photographic and chromatographic techniques. Our results show that there were no obvious foxing spots observed with the naked eye. However, foxing fluorescence spots appeared on paper under a normal atmosphere at $90 \% \mathrm{RH}$.

Paper preserved with an MA agent and stored under either a low- $\mathrm{O}_{2}$ or low- $\mathrm{O}_{2} /$ high- $\mathrm{CO}_{2}$ atmosphere showed no obvious foxing fluorescence for either $90 \%$ or $50 \% \mathrm{RH}$. With an MAH agent at $50 \% \mathrm{RH}$, even under a normal atmosphere, no presence of foxing on paper was found by the naked eye or under UV light.

\section{Conclusions}

Based on the experimental work conducted in this study, the following conclusions can be drawn. The MAH agent composed of $0.8 \mathrm{~g}$ of SA, $3.0 \mathrm{~g}$ of SC, and $0-4 \mathrm{~g}$ of silica gel was effective for reducing $\mathrm{O}_{2}$ levels and controlling $\mathrm{RH}$ to 
$86.3 \%-38.2 \%$. With this reagent combination, the $\mathrm{O}_{2}$ concentration was reduced and controlled to a stable $1.0 \% \pm$ $0.5 \%$ and the $\mathrm{CO}_{2}$ concentration was constantly below $0.5 \%$. On the other hand, the MAH agent composed of $1.3 \mathrm{~g}$ of SA, $2.6 \mathrm{~g}$ of SB, $2.2 \mathrm{~g}$ of FS, and $0-4 \mathrm{~g}$ of silica gel was effective in reducing $\mathrm{O}_{2}$ and releasing $\mathrm{CO}_{2}$, with $\mathrm{RH}$ controlled in the range $90.2 \%-35.6 \%$. With all the MAH agents developed in our study, the $\mathrm{RH}$ was reduced and maintained without reducing the efficiency of the MAH agents.

To evaluate the inhibition of microorganisms on antique paper by MAH agents, Wikstroemia papers were inoculated with Aspergillus flavus and Penicillium citrinum after accelerated aging. The visual appearance of the papers was then measured after conservation with MAH agents over time. As long as MAH agents were used, under conditions of $90 \%$ or $50 \% \mathrm{RH}$ and after 60 or 80 days, $\Delta E^{*}$ values for Wikstroemia paper were kept below 1.5. Wikstroemia paper packaged without MAH agents and at 90\% RH showed a substantial color difference in 60 days. Wikstroemia paper inoculated with $P$. citrinum showed a significant color difference in 80 days. Under UV light inspection, snowflake-like foxing was found on Wikstroemia paper packaged without MAH agents and at 90\% RH.

Acknowledgments The authors thank Professor Dr. Shang-Tzen Chang, School of Forestry and Resource Conservation, National Taiwan University, for his assistance with experiments.

\section{References}

1. Macinnes AN, Barron AR (1992) Spectroscopic evaluation of the efficacy of two mass deacidification processes for paper. J Mater Chem 2:1049-1056

2. Edwards T (1999) UK paper conservation courses: an overview. J Soc Arch 20:49-60

3. Wagner B, Bulska E, Hulanicki A, Heck M, Ortner HM (2001) Topochemical investigation of ancient manuscripts. Fresen J Anal Chem 369:674-679

4. Mosini V, Calvini P, Mattogno G, Righini G (1990) Derivative infrared spectroscopy and electron spectroscopy for chemical analysis of ancient paper documents. Cell Chem Technol 24:263272

5. Righini G, Segre AL, Mattogno G, Frederici C, Munafo PF (1998) An X-ray photoelectron spectroscopic study of ancient paper and its deterioration. Naturwissenschaften 85:171-175

6. Margutti S, Conio G, Calvini P, Pedemonte E (2001) Hydrolytic and oxidative degradation of paper. Restaurator 22:67-83

7. Chang FJ (1984) Aging of paper. Pulp Pap 11:65-70

8. Fabbri AA, Ricelli A, Brasini S, Fanelli C (1997) Effect of different antifungals on the control of paper biodeterioration caused by fungi. Int Biodeter Biodegr 39:61-65
9. Hirte WF, Glate I, Thuermer L (1987) Damage of paintings by fungi. Zentralbl Mikrobiol 142:271-282

10. Strzelczyk AB, Stanislawa L (1981) The role of fungi and bacteria in the consolidation of books. Int Biodeter Bull 17:57-67

11. Havermans JB (1994) The effects of air pollutants on accelerated ageing of cellulose containing materials: preliminary results of the project SEP (CT90-0100). In: Environnement et conservation de I'ecrit, de I'image et du son. Actes des douxiemes Journees Internationales d'etudes de I'arsag, Paris, pp 39-47

12. Kigawa R, Miura S, Yamano K (2000) Overview of the present alternative methods of methyl bromide fumigation for controlling pests in museums. J Jpn Soc Conserv Cultural Prop 44:52-69

13. Gilberg M (1990) Inert atmosphere disinfestations of museum objects using Ageless oxygen scavenger. Bull Aust Inst Conserv Cultural Mater 16:27-34

14. Valentin N, Preusser F (1990) Insect control by inert gases in museums, archives and libraries. Restaurator 11:22-23

15. Shiah TC, Chang TT, Fu CH (2001) The application of microwave irradiation for the disinfection of paper. Taiwan J Forest Sci $16: 327-332$

16. Lambert FL, Daniel V, Preusser FD (1992) The rate of absorption of oxygen by Ageless: the utility of an oxygen scavenger in sealed cases. Stud Conserv 37:267-274

17. Messier P (1997) Storage vault facilities for special collections. Symposium on the Management of Small and Medium Size Museums, Taipei, pp 53-80

18. Huang WH, Hsu CK, Chiang BH (1999) Formulations of controlled atmosphere agents for packaged foods. J Agric Food Chem 47:906-910

19. Wang PH, Hung TY (1999) A study on Aspergillus and Penicillium spp. isolated from a Chinese painting. J Chin Agric Chem Soc 34:481-488

20. Shiah TC, Chang FJ (2000) Effect of artificial induced foxing spots formation on paper-based materials. Q J Forest Res 22:7-20

21. Gallo $F$ (1994) The biodeterioration of library materials. In: Garg KL, Garg N, Mukerji KG (eds) Recent advances in biodeterioration and biodegradation, vol 1. Naya Prokash, Calcutta, India, pp 89-143

22. Chinese National Standard (CNS 12887-1) (1993) Accelerated aging of paper. Bureau of Standards, Metrology, and Inspection, Taipei, Taiwan

23. Stolow N (1987) Conservation and exhibitions: packing, transport, storage, and environmental consideration. ButterworthHeinemann

24. Shiah TC, Chang FJ (1999) Investigation on the formation mechanism of foxed spot appeared on paper-based cultural properties. Q J Forest Res 21:33-48

25. Arai H (1987) Application of scanning electron microscope in the field of conservation science of cultural properties. JEOL News 25:15-17

26. Cain CE, Miller BA (1982) Photographic spectral and chromatographic research into the nature of foxing. Preprints of the 10th Annual Meeting of the AIC, Milwaukee, pp 54-62

The publication of this article was made possible by an Emachu Research Fund. The authors are grateful for the fund. 